\title{
Gender-dependent difference in serum paraoxonase 1 levels of Hanwoo, Korean native cattle, and a positive association with meat quality
}

\author{
Jihyun Park', Jiwoo Kim', Sungwon Hwang ${ }^{1}$, Ki Young Chung ${ }^{2}$, Inho Choi ${ }^{1}$, \\ Chang Bon Choi ${ }^{1}$, and Jihoe $\mathrm{Kim}^{1, *}$
}

\footnotetext{
* Corresponding Author: Jihoe Kim Tel: +82-53-810-3032, Fax: +82-53-810-4769, E-mail: kimjihoe@ynu.ac.kr
}

${ }^{1}$ Department of Medical Biotechnology, Yeungnam University, Gyeongsan 38541, Korea

${ }^{2}$ Hanwoo Experiment Station, National Institute of Animal Science, RDA, Pyongchang 25340, Korea

ORCID

Jihyun Park

https://orcid.org/0000-0002-2396-8378

Jiwoo Kim

https://orcid.org/0000-0002-8162-9710

Sungwon Hwang

https://orcid.org/0000-0001-9422-9364

Ki Young Chung

https://orcid.org/0000-0003-0957-875X

Inho Choi

https://orcid.org/0000-0002-0884-5994

Chang Bon Choi

https://orcid.org/0000-0002-0053-9511

Jihoe Kim

https://orcid.org/0000-0002-1905-1452

Submitted Feb 16, 2018; Revised Jun 7, 2018; Accepted Aug 6, 2018
Objective: Paraoxonase 1 (PON1), a calcium-dependent serum enzyme, has been shown to be involved in lipid metabolism. In this study, we examined the putative correlation of the serum PON1 level of Hanwoo, Korean native cattle, with gender and meat quality grade. Methods: PON1 levels were estimated by determining the arylesterase and paraoxonase activities (AE and PO, respectively) in serum samples from Hanwoo individuals $(\mathrm{n}=56)$. Serum PON1 levels were analyzed in different gender groups (female $[n=21]$, castrated male $[n=$ $17]$, and male $[n=18])$, and meat quality grades $(\geq 1[n=23], 2[n=21]$, and $3[n=12])$. Results: Serum PON1 levels were similar in female $(\mathrm{AE}=120 \pm 55 \mathrm{U} / \mathrm{mL}, \mathrm{PO}=84 \pm 43 \mathrm{mU} / \mathrm{mL})$ and castrated male $(123 \pm 44 \mathrm{U} / \mathrm{mL}, \mathrm{PO}=89 \pm 30 \mathrm{mU} / \mathrm{mL})$, while male showed a significantly lower level $(\mathrm{AE}=65 \pm 43 \mathrm{U} / \mathrm{mL}, \mathrm{PO}=44 \pm 34 \mathrm{mU} / \mathrm{mL})$. Furthermore, analysis of serum PON1 levels in three different grades of meat quality showed similar levels in the grades $\geq 1$ ( $\mathrm{AE}=$ $118 \pm 49 \mathrm{U} / \mathrm{mL}, \mathrm{PO}=84 \pm 37 \mathrm{mU} / \mathrm{mL})$ and $2(\mathrm{AE}=116 \pm 54 \mathrm{U} / \mathrm{mL}, \mathrm{PO}=82 \pm 43 \mathrm{mU} / \mathrm{mL})$, while the level was significantly lower in the grade $3(\mathrm{AE}=58 \pm 35 \mathrm{U} / \mathrm{mL}, \mathrm{PO}=39 \pm 27 \mathrm{mU} / \mathrm{mL})$ of lower meat quality.

Conclusion: We discovered the gender-dependent differences in serum PON1 levels of Hanwoo and a positive association of the serum PON1 level with meat quality. Results in this study suggest that PON1 would be a useful serum marker for preliminary screening of Hanwoo individuals with high-quality meat and applicable for genetic improvement.

Keywords: Hanwoo; Serum paraoxonase 1; Gender-dependent Difference; Association with Meat Quality

\section{INTRODUCTION}

Paraoxonase 1 (PON1), a calcium-dependent serum enzyme, is primarily synthesized in the liver and secreted into blood, where it is associated with high density lipoprotein [1]. Although the physiological role of $\mathrm{PON} 1$ has not been clearly elucidated, $\mathrm{PON} 1$ was shown to be involved in a drug metabolism by hydrolyzing toxic metabolites of organophosphorus compounds used as insecticides and nerve agents [2-4]. PON1 also showed antioxidant activity preventing oxidation of lipids in low-density lipoproteins and high-density lipoproteins $[5,6]$. Moreover, serum PON1 levels were estimated to be low in obesity, insulin resistance and dyslipidemia [7], indicating the involvement of the enzyme in lipid metabolism. Polymorphic variants of human PON1 were reported to be significantly different in the enzyme activity of PON1 showing a positive association with the fatty acid composition of the adipose tissue [8]. Another study demonstrated an inverse correlation of PON1 activity with the thickness of epicardial adipose tissue, which suggested a possible role of PON1 in the regulation of the lipid com- 
position in body [9].

Hanwoo is a type of Korean native cattle and primary source of beef in Korea. Hanwoo beef is preferred over imported beef in Korean markets even though its price is twice as expensive, because consumers believe that Hanwoo beef have better quality $[10,11]$. It was reported that Hanwoo beef have greater scores of tenderness, juiciness, and flavor than imported beef from the United States and Australia [12]. Korea Institute for Animal Products Quality Evaluation (KAPE) established a beef carcass grading system consisting three levels of yield grade evaluating meat amount $(\mathrm{A}, \mathrm{B}$, and $\mathrm{C})$ and five levels of meat quality grade (higher to lower quality: $1^{++}, 1^{+}, 1,2$, and 3) [13]. Several factors, including marbling score, meat color, fat color, and firmness and texture are considered to determine the meat quality grade. However, marbling score is the most dominant determinant for beef meat grading, since fat and fatty acids importantly contribute to eating quality. Many studies have reported that palatability improves as marbling increases [1416]. In addition, marbling score is the most decisive criterion affecting purchase decisions, not only in Korea, but also in other countries [17,18].

Although most studies about PON1 focused on the human enzyme, PON1 was also found in bovine serum and its activity was shown to be a useful marker of diseases in dairy cows $[19,20]$. However, PON1 has been rarely investigated in cattles for meat production. Considering the possible role of PON1 in the regulation of the lipid composition and the most dominant determinant, marbling score, for Hanwoo meat quality grading, we examined the putative correlation of the serum PON1 level with gender and meat quality grade.

\section{MATERIALS AND METHODS}

\section{Materials and serum samples}

All chemicals were purchased from Sigma Aldrich, unless otherwise mentioned. Blood samples from 56 Hanwoo individuals ( 2 to 3 -year old female, $n=21$; 2 -year old males, $n=18$; 2 -year old castrated male, $n=17$ ) were collected in sterile bottles from a local slaughter-house in Pyeongchang, Kangwon Do, Republic of Korea. Meat quality grades were evaluated according to the KAPE carcass grading system [13]. Serum was isolated from collected blood samples and sterilized, as previously described [21], and stored at $-20^{\circ} \mathrm{C}$ until use. Protein concentrations of serum samples were determined by Bradford assay [22].

\section{Paraoxonase 1 activity assays}

The arylesterase and paraoxonase activities of PON1 were measured spectrophotometrically using the substrates phenylacetate and paraoxon (O,O-diethyl $O$-(4-nitrophenyl) phosphate), respectively [23]. Briefly, the arylesterase assay contained 1 $\mathrm{mM}$ phenylacetate in $20 \mathrm{mM}$ Tris- $\mathrm{HCl} \mathrm{pH} \mathrm{8.0,1} \mathrm{M} \mathrm{NaCl}$, and $1 \mathrm{mM} \mathrm{CaCl}_{2}$ at room temperature. The reaction was started by the addition of serum samples, and the formation of the reaction product, phenol, was followed at $270 \mathrm{~nm}(\varepsilon 270 \mathrm{~nm}$ $\left.=1.31 \mathrm{mM}^{-1} \mathrm{~cm}^{-1}\right)$. The paraoxonase assay contained $1 \mathrm{mM}$ paraoxon in the same buffer as described above. The addition of serum samples started the reaction and the formation of the reaction product, $p$-nitrophenol, was followed at $412 \mathrm{~nm}$ $\left(\varepsilon 412 \mathrm{~nm}=17.1 \mathrm{mM}^{-1} \mathrm{~cm}^{-1}\right)$. Enzyme activities were calculated from the initial slope of product formation and expressed in $\mathrm{U}(\mu \mathrm{mol} / \mathrm{min} \cdot \mathrm{mL})$ and $\mathrm{mU}(\mathrm{nmol} / \mathrm{min} \cdot \mathrm{mL})$ for arylesterase and paraoxonase activities, respectively.

\section{Statistical analysis}

Serum samples were grouped into three different genders of female $(n=21)$, castrated male $(n=17)$ and male $(n=18)$, and three different beef meat quality grades of $\geq 1(n=23), 2$ ( $n=$ $21)$, and $3(n=12)$. The average PON1 activities were expressed as the means \pm standard error. Differences in serum PON1 activities among genders and beef meat quality grades were analyzed by unpaired Student's t-test. A p value $<0.01$ was considered statistically significant.

\section{RESULTS AND DISCUSSION}

Serum samples were collected from 56 Hanwoo individuals, and grouped into three different gender groups (female, $n=21$; castrated male, $n=17$; male, $n=18$ ). The serum PON1 levels were then estimated by determination of the arylesterase and paraoxonase activities of PON1 (AE and PO, respectively) in serum samples (Table 1), as described in the materials and methods. The AE was determined to be highly variable in serum samples within the range of $\sim 20$ to $240 \mathrm{U} / \mathrm{mL}$, although serum protein concentrations were in the range of $\sim 60$ to 100 $\mathrm{mg} / \mathrm{mL}$. Statistical analyses showed similar AE of $120 \pm 55$ $\mathrm{U} / \mathrm{mL}$ and $123 \pm 44 \mathrm{U} / \mathrm{mL}$ in female and castrated male, respectively (Figure 1A). However, the AE was $65 \pm 43 \mathrm{U} / \mathrm{mL}$ in male and significantly lower than the activities in the other gender groups. The $\mathrm{PO}$ was also determined to be highly variable in serum samples within the range of $\sim 10$ to $200 \mathrm{mU} / \mathrm{mL}$. And, the PO was significantly lower in male $(44 \pm 34 \mathrm{mU} / \mathrm{mL})$ than in female and castrated male $(84 \pm 43 \mathrm{mU} / \mathrm{mL}$ and $89 \pm 30$ $\mathrm{mU} / \mathrm{mL}$, respectively) (Figure 1B). Analyses of AE and PO normalized by serum protein concentration consistently showed lower the PON1 activities in male than in other gender groups (Figure 1A, 1B). These results indicated the gender-dependent difference in serum PON1 levels of Hanwoo.

The gender-dependent difference in the serum PON1 level of Hanwoo suggested a putative correlation with meat quality, which prompted us to analyze the data in different meat quality groups. Analysis of the PON1 levels in three different meat quality grades $(\geq 1, \mathrm{n}=23 ; 2, \mathrm{n}=21 ; 3, \mathrm{n}=12)$ showed that $\mathrm{AE}$ were similar in the grade $\geq 1$ and $2(118 \pm 49 \mathrm{U} / \mathrm{mL}$ and $116 \pm 54 \mathrm{U} / \mathrm{mL}$, respectively (Figure $2 \mathrm{~A}$ ). While AE was $58 \pm 35$ 
Table 1. Summary of PON1 enzyme activities for serum samples grouped into different meat quality grades and genders ${ }^{1)}$

\begin{tabular}{|c|c|c|c|c|c|c|}
\hline Meat grade & Gender & $\begin{array}{l}\text { Serum protein } \\
\text { Conc. }(\mathrm{mg} / \mathrm{mL})\end{array}$ & $\begin{array}{c}\mathrm{AE}^{2)} \\
(\mathrm{U} / \mathrm{mL})\end{array}$ & $\begin{array}{c}\mathrm{AE}^{3)} \\
(\mathrm{U} / \mathrm{mg})\end{array}$ & $\begin{array}{c}\mathrm{PO}^{4)} \\
(\mathrm{mU} / \mathrm{mL})\end{array}$ & $\begin{array}{c}\mathrm{PO}^{5)} \\
(\mathrm{mU} / \mathrm{mg})\end{array}$ \\
\hline \multirow[t]{23}{*}{$\geq 1(n=23)$} & \multirow{10}{*}{$\begin{array}{l}\text { Castrated male } \\
(n=10)\end{array}$} & 62 & 105 & 1.70 & 79 & 1.28 \\
\hline & & 77 & 99 & 1.28 & 83 & 1.07 \\
\hline & & 67 & 87 & 1.29 & 63 & 0.93 \\
\hline & & 77 & 165 & 2.14 & 123 & 1.60 \\
\hline & & 68 & 129 & 1.89 & 83 & 1.22 \\
\hline & & 82 & 130 & 1.58 & 79 & 0.97 \\
\hline & & 68 & 84 & 1.23 & 69 & 1.01 \\
\hline & & 77 & 66 & 0.85 & 61 & 0.79 \\
\hline & & 61 & 62 & 1.03 & 54 & 0.89 \\
\hline & & 71 & 93 & 1.31 & 72 & 1.01 \\
\hline & \multirow[t]{2}{*}{ Male $^{6)}(n=2)$} & 107 & 77 & 0.72 & 47 & 0.44 \\
\hline & & 94 & 201 & 2.13 & 153 & 1.62 \\
\hline & \multirow[t]{11}{*}{ Female $(n=11)$} & 69 & 173 & 2.52 & 112 & 1.63 \\
\hline & & 99 & 162 & 1.63 & 111 & 1.11 \\
\hline & & 100 & 244 & 2.45 & 192 & 1.93 \\
\hline & & 66 & 105 & 1.60 & 78 & 1.19 \\
\hline & & 69 & 60 & 0.87 & 44 & 0.63 \\
\hline & & 64 & 142 & 2.21 & 100 & 1.56 \\
\hline & & 83 & 114 & 1.38 & 87 & 1.05 \\
\hline & & 61 & 131 & 2.15 & 76 & 1.25 \\
\hline & & 83 & 132 & 1.60 & 71 & 0.86 \\
\hline & & 62 & 26 & 0.42 & 21 & 0.33 \\
\hline & & 81 & 117 & 1.44 & 73 & 0.90 \\
\hline \multirow[t]{21}{*}{$2(n=21)$} & \multirow{7}{*}{$\begin{array}{l}\text { Castrated male } \\
(n=7)\end{array}$} & 59 & 106 & 1.80 & 64 & 1.08 \\
\hline & & 52 & 115 & 2.22 & 85 & 1.66 \\
\hline & & 102 & 232 & 2.27 & 152 & 1.48 \\
\hline & & 83 & 151 & 1.80 & 127 & 1.52 \\
\hline & & 83 & 171 & 2.07 & 140 & 1.70 \\
\hline & & 69 & 125 & 1.80 & 75 & 1.09 \\
\hline & & 108 & 168 & 1.56 & 117 & 1.09 \\
\hline & \multirow[t]{6}{*}{ Male $(n=6)$} & 56 & 39 & 0.69 & 28 & 0.49 \\
\hline & & 77 & 37 & 0.48 & 22 & 0.29 \\
\hline & & 100 & 45 & 0.45 & 13 & 0.13 \\
\hline & & 85 & 97 & 1.15 & 70 & 0.82 \\
\hline & & 80 & 59 & 0.74 & 47 & 0.60 \\
\hline & & 99 & 34 & 0.34 & 24 & 0.24 \\
\hline & \multirow[t]{8}{*}{ Female $(n=8)$} & 60 & 98 & 1.63 & 62 & 1.03 \\
\hline & & 68 & 123 & 1.82 & 113 & 1.68 \\
\hline & & 98 & 180 & 1.84 & 156 & 1.59 \\
\hline & & 75 & 126 & 1.68 & 80 & 1.08 \\
\hline & & 81 & 169 & 2.09 & 106 & 1.31 \\
\hline & & 88 & 160 & 1.82 & 108 & 1.22 \\
\hline & & 75 & 107 & 1.43 & 62 & 0.83 \\
\hline & & 63 & 100 & 1.60 & 71 & 1.13 \\
\hline \multirow[t]{12}{*}{$3(n=12)$} & \multirow[t]{10}{*}{ Male $(n=10)$} & 60 & 51 & 0.84 & 31 & 0.51 \\
\hline & & 67 & 27 & 0.40 & 24 & 0.36 \\
\hline & & 60 & 76 & 1.26 & 52 & 0.86 \\
\hline & & 61 & 109 & 1.80 & 57 & 0.93 \\
\hline & & 65 & 40 & 0.62 & 23 & 0.36 \\
\hline & & 66 & 52 & 0.79 & 32 & 0.49 \\
\hline & & 68 & 31 & 0.46 & 9 & 0.13 \\
\hline & & 92 & 19 & 0.21 & 12 & 0.13 \\
\hline & & 98 & 78 & 0.79 & 54 & 0.55 \\
\hline & & 101 & 108 & 1.07 & 87 & 0.87 \\
\hline & \multirow[t]{2}{*}{ Female $^{7)}(n=2)$} & 69 & 34 & 0.50 & 29 & 0.42 \\
\hline & & 69 & 15 & 0.22 & 9 & 0.13 \\
\hline
\end{tabular}

PON1, paraoxonase 1; $\mathrm{AE}$, arylesterase activity; $\mathrm{PO}$, paraoxonase activity.

1) Mean values for the groups of genders and meat grades are compared in Figure 1 and 2, respectively. 2), 4) Arylesterase and paraoxonase volume activities, respectively.

3), 5) Arylesterase and paraoxonase activities, respectively, normalized by serum protein concentrations.

${ }^{6}$ Males in the grade $\geq 1$ showed serum PON1 levels higher than the average level of the male group.

7) Females in the grade 3 showed serum PON1 levels lower than the average level of the female group.
$\mathrm{U} / \mathrm{mL}$ in the grade 3 and significantly lower than the activities in the other meat grade groups (Figure 2A). Consistently, the $\mathrm{PO}$ in the grade 3 was $39 \pm 27 \mathrm{mU} / \mathrm{mL}$, which was significantly lower than in the grade $\geq 1$ and $2(84 \pm 37 \mathrm{mU} / \mathrm{mL}$ and $82 \pm 43$ $\mathrm{mU} / \mathrm{mL}$, respectively) (Figure $2 \mathrm{~B}$ ). AE and PO normalized by serum protein concentration were consistently lower in the grade 3 than in the other meat grade groups (Figure 2A and $2 B)$. The grade $\geq 1$ included mostly females $(n=11)$ and castrated males $(n=10)$, and only two males. Interestingly, males in the grade $\geq 1$ showed serum PON1 levels (AE activities = $77 \mathrm{U} / \mathrm{mL}$ and $201 \mathrm{U} / \mathrm{mL}, \mathrm{PE}$ activities $=47 \mathrm{U} / \mathrm{mL}$ and 152 $\mathrm{U} / \mathrm{mL}$ ) higher than the average level of the male group (Table $1)$. Moreover, the grade 3 included mostly males $(n=10)$, and two females. Serum PON1 levels of two females in the grade $3(\mathrm{AE}$ activities $=16 \mathrm{U} / \mathrm{mL}$ and $34 \mathrm{U} / \mathrm{mL}, \mathrm{PO}$ activities $=9$ $\mathrm{mU} / \mathrm{mL}$ and $29 \mathrm{mU} / \mathrm{mL}$ ) were much lower than the average level of the female group (Table 1). The grade 2 included eight females, seven castrated males and six males. The average serum PON1 activity level of males in the grade 2 (AE activity $=52 \pm 24 \mathrm{U} / \mathrm{mL}, \mathrm{PO}$ activity $=34 \pm 21 \mathrm{mU} / \mathrm{mL}$ ) was not significantly different from the average level of the male group.

The mean values of serum PON1 levels obtained in this study were with rather high deviations, which might be due to fixed effect. However, when the same experiment was carried out multiple times with another sets of samples, data analysis showed similar extend of deviations, but with consistent genderdependent differences in serum PON1 levels and the positive association with meat quality. Therefore, we concluded that the high deviations of mean values were mostly due to a few number of samples with exceptional high or low PON1 levels in each gender group and meat quality grade. These exceptional serum samples implicated that certain genetic or environmental factors could be related with serum PON1 levels. Age, body weight and feeding conditions might affect serum PON1 levels, which could not be considered and analyzed in this study due to the limited sample numbers and insufficiently controlled managing environments. Nevertheless, we could not exclude the data of exceptional high or low PON1 levels for analysis, since they were from rare samples, such as males in the meat grade $\geq 1$ and females in the meat grade 3 .

Bovine gender is a well-known factor that affects marbling score and meat quality. Marbling score was shown to be significantly higher in female and castrated male than in male, regardless of bovine species, indicating possible roles of sex hormones in the regulation of fat deposition $[24,25]$. The gender-dependent difference in serum PON1 levels of Hanwoo indicated a close relation with sex hormones, which was not observed in humans [26]. The positive association of serum PON1 levels with meat quality could be due to more males in the grade 3 than the other meat grade groups. However, a few females in the grade 3 with very low PON1 levels and males in the grade 1 with high PON1 levels suggested that differences 
A

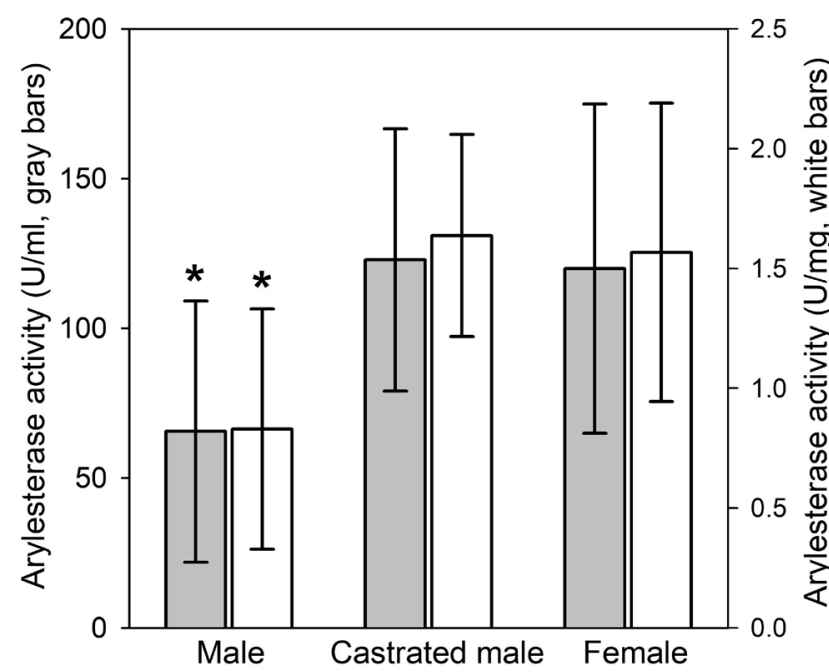

B

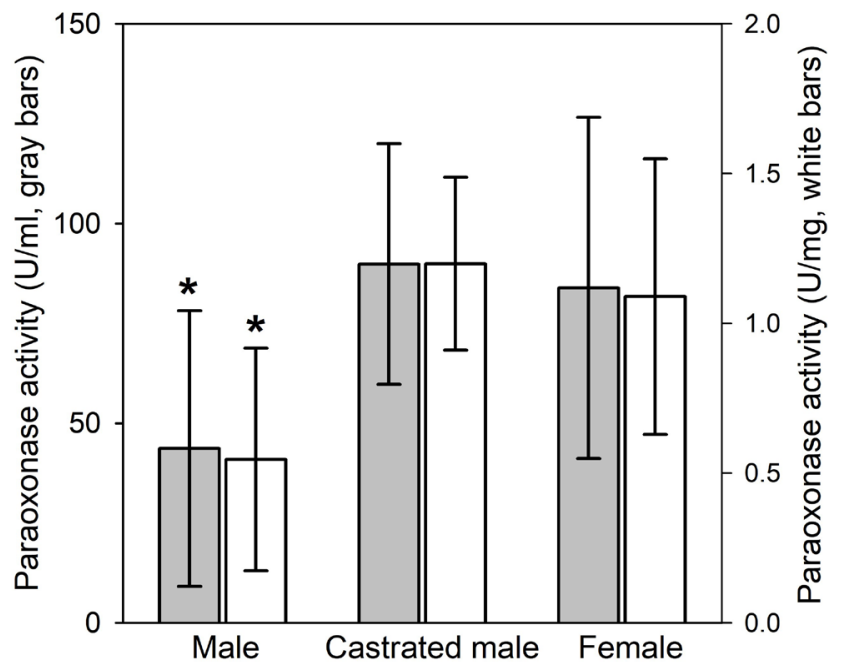

Figure 1. Gender-dependent differences in serum paraoxonase 1 (PON1) levels. PON1 enzyme acitivities in Table 1 were grouped into different groups of genders. Mean values of gender groups are compared for arylesterase (A) and paraoxonase (B) acitivities. Gray bars are for volume activities (U/mL or $\mathrm{mU} / \mathrm{mL})$ and white bars are for activities normalized by serum proteins concentrations (U/mg or mU/mg). * The serum PON1 level in male is significantly lower (statistical significance of $p<0.001)$ than the levels in female and castrated male.

in serum PON1 levels might be, not only gender-dependent, but also dependent of a certain genetic factor(s). Certain polymorphic variants of human PON1 showed high enzyme activities and a positive association with the fatty acid composition in the body $[8,9]$. The positive association of serum PON1 levels with meat quality implicates the PON1 polymorphism that needs to be investigated for the genetic improvement of Hanwoo.

In conclusion, we discovered a gender-dependent difference in serum PON1 levels of Hanwoo, which was significantly lower in male than in female and castrated male. Furthermore, the serum PON1 level was positively associated with meat quality, showing lower levels in the lower meat quality group of the grade 3 than in higher meat quality groups of the grade $\geq 1$ and 2 . Results in this study suggest that PON1 would be a useful serum marker for preliminary screening of Hanwoo individuals with high-quality meat and applicable for genetic improvement.
A

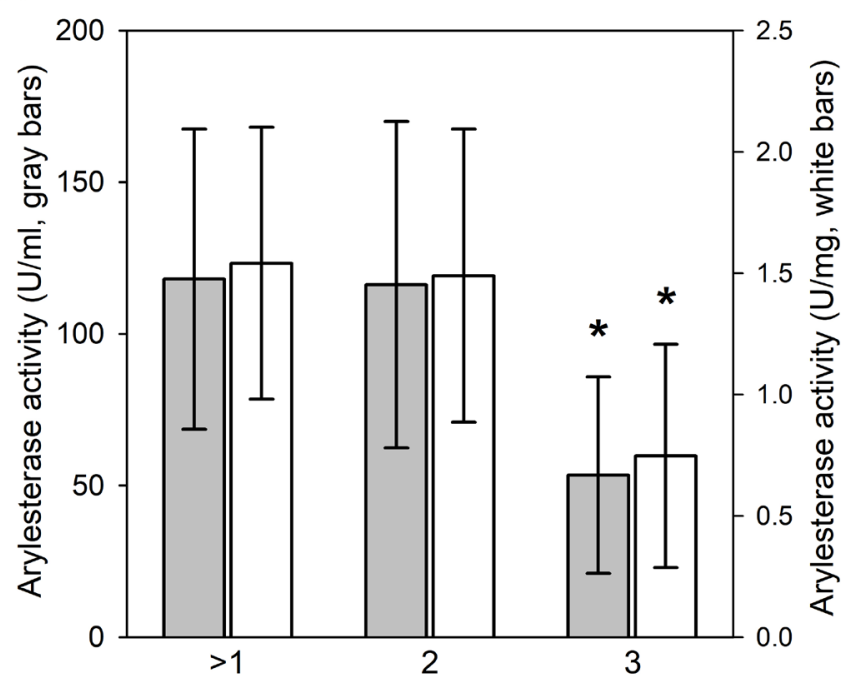

B

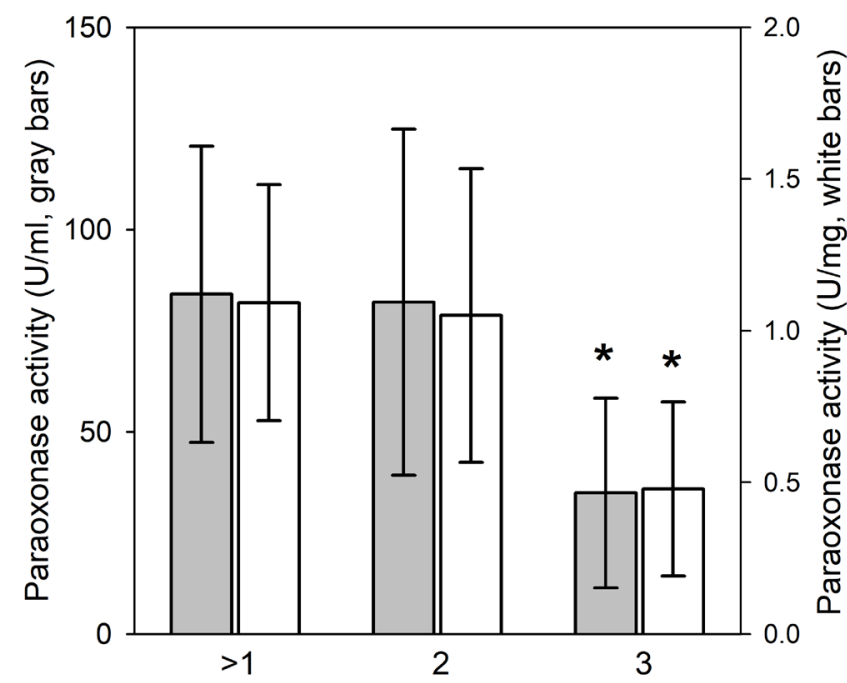

Figure 2. Positive association of serum paraoxonase 1 (PON1) level with meat quality. PON1 enzyme acitivities in Table 1 were grouped into different groups of meat quality grades. Mean values of meat quality groups were compared for arylesterase (A) and paraoxonase (B) acitivities. Gray bars are for volume activities (U/mL or $\mathrm{mU} / \mathrm{mL}$ ) and white bars are for activities normalized by serum proteins concentrations (U/mg or mU/mg). * The serum PON1 level in the grade 3 is significantly lower (statistical significance of $p<0.001$ ) than the levels in the grade $\geq 1$ and 2 . 


\section{CONFLICT OF INTEREST}

We certify that there is no conflict of interest with any financial organization regarding the material discussed in the manuscript.

\section{ACKNOWLEDGMENTS}

This research was supported by Basic Science Research Program through the National Research Foundation of Korea (NRF) funded by the Ministry of Education, Science and Technology (NRF-2014R1A1A2A16054759, NRF-2016R1D1A1B 03932659).

\section{REFERENCES}

1. Gugliucci A, Caccavello R, Kotani K, et al. Enzymatic assessment of paraoxonase 1 activity on HDL subclasses: a practical zymogram method to assess HDL function. Clin Chim Acta 2013;415:162-8.

2. Costa LG, Cole TB, Jarvik GP, et al. Functional genomic of the paraoxonase (PON1) polymorphisms: effects on pesticide sensitivity, cardiovascular disease, and drug metabolism. Annu Rev Med 2003;54:371-92.

3. Sozmen EY, Mackness B, Sozmen B, et al. Effect of organophosphate intoxication on human serum paraoxonase. Hum Exp Toxicol 2002;21:247-52.

4. Davies HG, Richter RJ, Keifer M, et al. The effect of the human serum paraoxonase polymorphism is reversed with diazoxon, soman and sarin. Nat Genet 1996;14:334-6.

5. Mackness MI, Arrol S, Durrington PN. Paraoxonase prevents accumulation of lipoperoxides in low-density lipoprotein. FEBS Lett 1991;286:152-4.

6. Mackness MI, Arrol S, Abbott C, et al. Protection of low-density lipoprotein against oxidative modification by high-density lipoprotein associated paraoxonase. Atherosclerosis 1993;104: 129-35.

7. Kota SK, Meher LK, Jammula S, et al. Implications of serum paraoxonase activity in obesity, diabetes mellitus, and dyslipidemia. Indian J Endocrinol Metab 2013;17:402-12.

8. Zafiropoulos A, Linardakis M, Jansen EH, et al. Paraoxonase $1 \mathrm{R} / \mathrm{Q}$ alleles are associated with differential accumulation of saturated versus 20:5n3 fatty acid in human adipose tissue. J Lipid Res 2010;51:1991-2000.

9. Abdallah E, El-Shishtawy S, Sherif N, et al. Assessment of the relationship between serum paraoxonase activity and epicardial adipose tissue in hemodialysis patients. Int Urol Nephrol 2017;49:329-35.

10. Han SW, Lee BO. A Study on the purchasing behaviour of consumers for domestic and imported beef in Korea. J Agric Life Sci 2010;22:73-89.
11. Chung KY, Lee SH, Cho SH, et al. Current situation and future prospects for beef production in South Korea - a review. AsianAustralas J Anim Sci 2018;31:951-60.

12. Jo C, Cho SH, Chang J, et al. Keys to production and processing of Hanwoo beef: A perspective of tradition and science. Anim Front 2012;2:32-8.

13. The beef carcass grading [Internet]. Korea Institute for Animal Products Quality Evaluation; 2012 [cited 2012 May 15]. Available from: http://www.ekape.or.kr/view/eng/system/beef.asp

14. Savell JW, Baranson RE, Cross HR, et al. National consumer retail beef study: palatability evaluations of beef loin steaks that differed in marbling. J Food Sci 1987;52:517-9.

15. Seideman SC, Koohmaraie M, Crouse JD. Factors associated with tenderness in young beef. Meat Sci 1987;20:281-91.

16. Tatum JD, Smith GC, Berry BW, et al. Carcass characteristics, time on feed and cooked beef palatability attributes. J Anim Sci 1980;50:833-40.

17. Grunert KG, Bredahl L, Brunso K. Consumer perception of meat quality and implications for product development in the meat sector-a review. Meat Sci 2004;66:259-72.

18. Gonzalez JM, Phelps KJ. United States beef quality as chronicled by the national beef quality audits, beef consumer satisfaction projects, and national beef tenderness surveys - a review. AsianAustralas J Anim Sci 2018;31:1036-42.

19. Kulka M, Kołodziejska-Lesisz J, Kluciński W. Serum paraoxonase 1 (PON1) activity and lipid metabolism parameters changes in different production cycle periods of Holstein-Friesian, Polish Red and Norwegian breeds. Pol J Vet Sci 2016;19:165-73.

20. Kulka M, Bełtowski J, Kluciński W, et al. Serum paraoxonase-1 activity of dairy Holstein-Fresian cows in different lactation stages - preliminary study. Pol J Vet Sci 2014;17:143-7.

21. Kim J, Kim M, Nahm SS, et al. Characterization of genderspecific bovine serum. Anim Cells Syst 2011;15:147-54.

22. Bradford MM. A rapid and sensitive method for the quantitation of microgram quantities of protein utilizing the principle of protein-dye binding. Anal Biochem 1976;72:248-54.

23. Eckerson HW, Wyte CM, La Du BN. The human serum paraoxonase/arylesterase polymorphism. Am J Hum Genet 1983; 35:1126-38.

24. Jones DK, Savell JW, Cross HR. The influence of sex-class, USDA yield grade and USDA quality grade on seam fat trim from the primals of beef carcasses. J Anim Sci 1990;68:198791.

25. Park GB, Moon SS, Ko YD, et al. Influence of slaughter weight and sex on yield and quality grades of Hanwoo (Korean native cattle) carcasses. J Anim Sci 2002;80:129-36.

26. Geldmacher-von Mallinckrodt M, Diepgen TL, Duhme C, et al. A study of the polymorphism and ethnic distribution differences of human serum paraoxonase. Am J Phys Anthropol 1983;62:235-41. 